\title{
Analytical Method Assessment for the Determination of DHA and Fatty Acids Present in Unextracted Aurantiochytrium limacinum Biomass
}

\author{
Gerald Patrick Dillon $^{1 *}{ }^{\circledR}$, Alexandros Yiannikouris ${ }^{2}{ }^{\circledR}$, Walter Brandl ${ }^{3}$, Cathy Cardinall ${ }^{3}$, \\ Wendy Yuan ${ }^{3}$, Colm Anthony Moran4 (i) \\ ${ }^{1}$ Regulatory Affairs Department, Alltech Ireland, Dunboyne, Ireland \\ ${ }^{2}$ Research Department, Alltech Inc., Nicholasville, USA \\ ${ }^{3}$ Analytical Chemistry Department, Mérieux Nutri Sciences, Burnaby, Canada \\ ${ }^{4}$ Regulatory Affairs Department, Alltech SARL, Vire, France \\ Email: gdillon@alltech.com
}

How to cite this paper: Dillon, G.P., Yiannikouris, A., Brandl, W., Cardinall, C., Yuan, W. and Moran, C.A. (2019) Analytical Method Assessment for the Determination of DHA and Fatty Acids Present in Unextracted Aurantiochytrium limacinum Biomass. Food and Nutrition Sciences, 10, 469-483.

https://doi.org/10.4236/fns.2019.104035

Received: March 25, 2019

Accepted: April 25, 2019

Published: April 28, 2019

Copyright (๑) 2019 by author(s) and Scientific Research Publishing Inc. This work is licensed under the Creative Commons Attribution International License (CC BY 4.0).

http://creativecommons.org/licenses/by/4.0/ (c) (i) Open Access

\begin{abstract}
Research into long-chain polyunsaturated fatty acids (LC-PUFA), such as docosahexaenoic acid (DHA C22:6n-3), has shown that their inclusion in the human diet is linked with many health benefits. This has led to an increased interest in the enrichment of certain foodstuffs with DHA by supplementing animal fed with DHA-rich ingredients which can lead to an increased uptake in the meat, milk and eggs animal by-products. The microalgae Aurantiochytrium limacinum has been found to be especially useful in this pursuit. It is subsequently desirable to availably have a simple and robust method for the routine analysis of DHA and other fatty acids in the algal biomass. The AOAC method 996.06 is often followed for the analysis of fatty acids in foods and demonstrating that its fitness for purpose in the analysis of DHA and additional fatty acids in Aurantiochytrium limacinum is therefore the objective of this paper. A validation of the method for the determination of DHA and three other fatty acids in Aurantiochytrium limacinum is presented. The method was found to be linear over the following ranges for each fatty acid methyl ester (FAME) analyte; 50 to $15,000 \mu \mathrm{g} / \mathrm{ml}$ (C14:0), 300 to 95,000 (C16:0), 25 to 15,000 (C18:0) and 300 to 59,375 (C22:6). The accuracy, precision and LOD and LOQ of the method were confirmed and its robustness tested. The application of the method to assess the stability of Aurantiochytrium limacinum containing two alternative antioxidants was further examined. The investigation showed that DHA was stable over six months with the inclusion
\end{abstract}


of either Duralox ${ }^{\oplus}$ or ethoxyquin as an antioxidant and ethoxyquin could additionally stabilize DHA in Aurantiochytrium limacinum up to 24 months.

\section{Keywords}

DHA, GC-FID, Fatty Acids, Analytical Method, Fitness for Purpose, Aurantiochytrium limacinum

\section{Introduction}

In recent times, research into long-chain polyunsaturated fatty acids (LC-PUFA) has shown that they are associated with a range of health benefits including; improved brain development and cognitive function [1] as well as a reduction in the risk of depression [2], inflammatory processes [3] and cardiovascular disease [4]. LC-PUFA can be further classified as omega-6 (n-6) and omega-3 (n-3) fatty acids, where appropriate levels of both are required for optimum health [5]. The omega-3 fatty acid DHA is considered to be particularly important in the human diet as it is not easily derived in the body and must be supplemented through food sources [6]. Despite the awareness surrounding DHA, intake remains low in populations consuming a westernized diet [7]. Some estimates suggest that $80 \%$ of adults consume less than the recommended amount of DHA [8].

In order to address the deficiency of DHA in the human diet, enrichment of commonly consumed foods has gained popularity among researchers and food producers [9]. The DHA content of foods, such as animal by product, can be fortified by supplementing animal fed with ingredients rich in DHA [9] [10]. DHA enrichment of common food sources can therefore lead to a greater availability and accessibility of food choices rich in DHA and furthermore an increased consumption of DHA without any significant change to consumer diets [6].

Dietary supplementation of intensively farmed animals with fish oils, rich in both the omega-3 fatty acids DHA and eicosapentaenoic acid (EPA), has been used to increase the omega- 3 content of animal meat, milk and egg products; [11] [12]. However, due to a global decline in fish stocks, as well as issues related to the stability to autoxidation of processed fish oils, a move to more sustainable alternatives of omega-3 rich feed supplements is desirable. Heterotrophically grown microalgae represent an alternative source containing high concentrations of protected DHA and can be used to supplement animal feed [13] [14]. The algal subject of this paper, Aurantiochytrium limacinum is a microalgae that has been shown to increase the DHA content of milk [15] [16], of pig muscle tissue [17] [18], broiler [19] and of laying hen eggs [20] when supplemented to the animal diets.

It is subsequently necessary to be able to quantify the fatty acid concentrations in DHA-rich feed ingredients. This can be achieved by using various methods such as Thin Layer Chromatography (TLC) interfaced with detection techniques such as Flame Ionization Detection (FID) and Matrix Assisted Laser Desorption 
Ionization Mass Spectrometry (MALDI-MS) [21] Likewise, Gas Chromatography (GC) and Liquid Chromatography (LC) methods hyphenated with various Mass Spectrometry (MS) detection systems which can yield a comprehensive fatty acid speciation of test subjects [22]. However, for routine and robust fatty acid analysis, GC-FID represents the method of choice due to its specific, sensitive and rapid analysis [23].

The fatty acid content in food \& feed is commonly determined by extraction from their relevant sources using the method developed by Folch et al. [24] and by synthesising respective fatty acid methyl esters (FAME), which are then analysed by GC [25] [26]. The AOAC method 996.06, for example, is routinely followed for this purpose [27]. GC-FID has been reported in several research publications on the analysis of fatty acids in food and feed ingredients including the analysis of microalgae [28] [29]. Whilst these papers provide useful information on fatty acid content in a range of settings, there has not been up to now, a published demonstration of the fitness for purpose of the methodology for analysing DHA in an unextracted microalgae biomass in dry powder form. Moreover, this is the first disclosure of the DHA analysis of the specific strain of Aurantiochytrium limacinum. As algae has emerged as an ingredient of enormous potential for use in the enrichment of food, there is a need for a simple and robust method for the routine analysis of algae to monitor its FA composition and evaluate if they meet the desired specification.

The objective of this paper therefore is to establish the fitness for purpose vis-a-vis a validation of the method, AOAC 996.06, for the determination of DHA and other fatty acids present in the unextracted biomass of a heterotrophically grown and spray-dried Aurantiochytrium limacinum; specifically, tetradecanoic acid $\left(\mathrm{C}_{14: 0}\right)$, hexadecanoic acid $\left(\mathrm{C}_{16: 0}\right)$, octadecanoic acid $\left(\mathrm{C}_{18: 0}\right)$. The parameters investigated as part of the validation study included; linearity and range, accuracy and precision, selectivity and the limit of detection (LOD) and limit of quantification (LOQ). A further objective of the paper was to apply the method to the stability assessment of DHA in respective batches of Aurantiochytrium limacinum containing two alternative antioxidants, ethoxyquin and Duralox $^{\oplus}$. Ethoxyquin has been widely used as an antioxidant in foods of animal origin and animal feed [30]. However, in 2017, the European Commission suspended its use as a technological additive in all species citing safety concerns of impurities and metabolites associated with the additive [31]. With a view to assessing the stability using a more natural alternative, the authors conducted a 6-month stability trial on batches of Aurantiochytrium limacinum containing Duralox $^{\varpi}$ and compared the results to batches containing ethoxyquin. Duralox ${ }^{\circledast}$ is a commercial antioxidant containing rosemary extract and tocopherols.

\section{Materials and Methods}

\subsection{Instrumentation and Chemicals \& Reagents}

The verification experiments were performed at Mérieux NutriSciences (Burnaby, Canada) in compliance with ISO 17025 requirements and ICH Q2B Guide- 
lines. All experiments were performed on an Agilent 6890N gas chromatograph (Agilent, Ontario, Canada) equipped with a hydrogen FID and an Agilent 7683 autosampler (Agilent, Ontario, Canada). Solvents and reagents used during the extraction and methylation steps were sourced from Fisher Scientific (Ontario, Canada). These included diethyl ether, petroleum ether, water (HPLC grade), ethanol 95\%, chloroform, toluene, hexane and methanol. Boron trifluoride, 7\% was prepared by diluting boron fluoride $14 \%$ one to one with methanol. Hydrochloric acid, $8.3 \mathrm{~N}$ was prepared by adding $250 \mathrm{ml}$ of concentrated $\mathrm{HCl}(12 \mathrm{~N})$ to $110 \mathrm{ml}$ of deionized water. Pyrogallic acid was obtained from TCI America (Portland, USA).

The FAME reference solution (GLC-85) and the standards solutions comprising: methyl 4,7,10,13,16,19-docosahexaenoate; methyl octadecenoate, methyl hexadecanoate; and methyl tetradecenoate; internal standard for sample extraction, 1,2,3-triundecanoylglycerol (common name: triundecanoin, $\mathrm{C}_{11: 0}$ ); internal standards for calibration curve, methyl undecanoate and docosahexaenoic acid (DHA) were purchased from Nu-Chek-Prep Inc. (Minnesota, USA). The test microalgae sample (Unextracted Aurantiochytrium limacinum CCAP 4087/2) was provided by Alltech Inc. (Nicholasville, KY, USA).

\subsection{Preparation of Stock Solutions, Internal Standards and Calibration Standards}

The FAME standard stock solutions were prepared by dissolving $1.00 \pm 0.05 \mathrm{~g}$ of commercial standards in hexane in a volumetric flask. A mixed FAME spiking solution with a final concentration of $10 \mathrm{mg} / \mathrm{ml}$ for $\mathrm{C}_{14: 0}$ and $\mathrm{C}_{18: 0}$ and $100 \mathrm{mg} / \mathrm{ml}$ for $\mathrm{C}_{16: 0}$ and $\mathrm{C}_{22: 6}$ were prepared from the FAME standard stock solution in a final volume of $10 \mathrm{ml}$ of hexane. A mixed FAME spiking solution for the defatted matrix analysis with a final concentration of $2.5 \mathrm{mg} / \mathrm{ml}$ for $\mathrm{C}_{14: 0}, 25 \mathrm{mg} / \mathrm{ml}$ for $\mathrm{C}_{16: 0}, 1.25 \mathrm{mg} / \mathrm{ml}$ for $\mathrm{C}_{18: 0}$ and $62.5 \mathrm{mg} / \mathrm{ml}$ for $\mathrm{C}_{22: 6}$ was prepared by taking an aliquot of each FAME standard stock solution in a final volume of $10 \mathrm{ml}$ of hexane. A methyl undecanoate internal standard solution was prepared in hexane with $1 \mathrm{~g}$ of methyl undecanoate, in a final volume of $10 \mathrm{ml}$ using a volumetric flask. Linearity experiments were conducted over the following concentrations ranges of each analyte by adding given volumes of FAME standard solution to $100 \mu \mathrm{l}$ of methyl undecanoate internal standard solution and making up to 2000 $\mu \mathrm{l}$ with hexane. When not in use, solutions were stored at $<-16^{\circ} \mathrm{C}$. Linearity was established using 6-point calibration curves ranging from: 50 to $15,000 \mu \mathrm{g} / \mathrm{ml}$ $\left(\mathrm{C}_{14: 0}\right), 300$ to $95,000\left(\mathrm{C}_{16: 0}\right), 25$ to $15,000\left(\mathrm{C}_{18: 0}\right)$ and 300 to $59,375\left(\mathrm{C}_{22: 6}\right)$ and amended with $\mathrm{C}_{11: 0}$ internal standard.

\subsection{Preparation of Aurantiochytrium Biomass}

In order to further explore the suitability of the method, a second test sample with an alternative matrix composition-defatted algae powder-was prepared and subjected to accuracy and precision experiments similar to the primary non-defatted algal test sample. To make the defatted matrix, algae powder was 
blended with water and then dried in a vacuum oven at $70^{\circ} \mathrm{C}$. The sample was rinsed with acetone to remove excess water and then extracted using a soxhlet apparatus with petroleum ether. The soxhlet program was set to extract $45 \mathrm{~min}$ utes and rinse 45 minutes, followed by drying for 1 hour.

\section{Extraction of Fat}

Control algae powder was thoroughly mixed to ensure a homogeneous sample was obtained. A $0.15 \pm 0.01 \mathrm{~g}$ sample of the powder was weighed into a Mojonnier flask. For spiked algae samples, respective volumes of 100, 200 and $300 \mu \mathrm{l}$ of mixed FAME stock solution were separately added into control algae samples to achieve the spike concentrations as outlined in Table 4 and Table 5. Pyrogallic acid (100 mg) was added to the flask which was then fortified with $75 \mu \mathrm{l}$ of 40 $\mathrm{mg} / \mathrm{ml}$ mixed FAME standard working solution. A $2 \mathrm{ml}$ aliquot of triundecanoin internal standard solution, a few boiling granules and $2 \mathrm{ml}$ of ethanol was added. The sample was mixed until completely wet. A $10 \mathrm{ml}$ aliquot of $8.3 \mathrm{M}$ hydrochloric acid was added. The flask was placed in a $70^{\circ} \mathrm{C}-80^{\circ} \mathrm{C}$ water bath for one hour and the contents were mixed every ten minutes before being cooled to $20^{\circ} \mathrm{C}$ and vortex-mixed for 15 seconds. Excess ethanol was added to rinse down all particles adhering to the walls of the flask. A $25 \mathrm{ml}$ portion of diethyl ether was added to the flask, which was stoppered and shaken gently. A $25 \mathrm{ml}$ portion of petroleum ether was added, and the flask was again shaken and vortex-mixed for two minutes. The flask was centrifuged for five minutes at 600 rpm to yield a clear supernatant, which was decanted into a round bottomed flask and evaporated using a rotary evaporator and nitrogen to remove any residual solvent.

\section{Methylation}

The extracted fat residue was dissolved in $3 \mathrm{ml}$ of chloroform. A $3 \mathrm{ml}$ volume of diethyl ether was added, and the resulting solution was placed into a $10 \mathrm{ml}$ glass tube. The round bottomed flask was washed with diethyl ether and the washings were added to the glass tube. The solution in the glass tube was evaporated to dryness under nitrogen at $40^{\circ} \mathrm{C}$. A $2 \mathrm{ml}$ volume of $7 \% \mathrm{BF} 3$ reagent and $1 \mathrm{ml}$ of toluene was added to the glass tube which was vortex-mixed for $30 \mathrm{sec}-$ onds. The tube was sealed tightly with a screw-cap top with a Teflon/silicone septum and heated in an oven for one hour at $100^{\circ} \mathrm{C}$ with gentle shaking every ten minutes. The tube was allowed to cool to $20^{\circ} \mathrm{C}$ and $5 \mathrm{ml}$ of HPLC-grade water, $1 \mathrm{ml}$ hexane and about $1 \mathrm{~g}$ sodium sulfate were added. The tube was capped and vortex-mixed for one minute and then centrifuged at $2000 \mathrm{rpm}$ for $3 \mathrm{~min}$ utes. The resulting clear supernatant was dried again with sodium sulfate and injected into the GC-FID.

\section{GC-FID Conditions}

The GC system utilized a SP2560 $100 \mathrm{~cm}$ long capillary column, $0.25 \mathrm{~mm}$ internal diameter; $0.20 \mu \mathrm{m}$ film thickness (Supelco, Pennsylvania, USA). The system used helium as a carrier gas with an initial flow of $1.1 \mathrm{ml} / \mathrm{min}$ and an average velocity of $19 \mathrm{~cm} / \mathrm{sec}$ at a pressure of $35.74 \mathrm{psi}$. Air and hydrogen were used for the FID with pressures of 60 and 40 psi respectively. The initial oven tem- 
perature was $100^{\circ} \mathrm{C}$ which was held for four minutes and then ramped up at a rate of $3^{\circ} \mathrm{C} / \mathrm{min}$ to $240^{\circ} \mathrm{C}$ and held for 19 minutes. The injector was employed in the split mode at a ratio of $200: 1$ and at a temperature of $225^{\circ} \mathrm{C}$. The detector temperature was set to $285^{\circ} \mathrm{C}$. System suitability was evaluated using the calibration GLC-85 reference FAME standards injected in five replicates.

\subsection{Method Verification}

\section{Specificity}

Blank algae powder samples were analyzed in six replicates and in three replicates on two successive days by the primary analyst and in three replicates on the second day by a secondary analyst in order to determine the endogenous levels of the analytes $\mathrm{C}_{14: 0}, \mathrm{C}_{16: 0}, \mathrm{C}_{18: 0}$ and $\mathrm{C}_{22: 6}$. In addition, an algae powder sample was spiked with a low concentration of analytes to determine if the method could distinguish between the analytes of interest and other interfering substances of the matrix.

\section{Linearity}

Standard curves of the respective analytes and a suitable range of concentrations were prepared to demonstrate linearity of the method. Linear regression, forced through the origin and with equal weighting, was applied to the peak area ratios plot for the construction of calibration curves and to provide information on the slope, coefficient of determination, and intercept.

\section{Accuracy}

In order to determine the accuracy of the method, blank algae powder was spiked with $\mathrm{C}_{14: 0}, \mathrm{C}_{16: 0}, \mathrm{C}_{18: 0}$ and $\mathrm{C}_{22: 6}$ in FAME form at three concentration levels as followed and \% recoveries were calculated:

- $\mathrm{C}_{14: 0}$ was spiked to final concentrations of approximately $3.2 \%, 3.9 \%$ and $4.6 \%(\mathrm{w} / \mathrm{v})$,

- $\mathrm{C}_{16: 0}$ was spiked to final concentrations of approximately $41.3 \%, 48.0 \%$ and $54.6 \%(\mathrm{w} / \mathrm{v})$,

- $\mathrm{C}_{18: 0}$ was spiked to final concentrations of approximately $1.7 \%, 2.4 \%$ and $3.0 \%(\mathrm{w} / \mathrm{v})$, and

- C22:6 n3 was spiked to final concentrations of approximately $25.7 \%, 32.4 \%$ and $39.1 \%(\mathrm{w} / \mathrm{v})$.

The accuracy study was repeated using a defatted blank matrix which contained the following concentrations of the fatty acid analytes; $\mathrm{C}_{14: 0} 1.4 \%, \mathrm{C}_{16: 0}$ $15.4 \%, \mathrm{C}_{18: 0} 0.48 \%$ and $\mathrm{C}_{22: 6} 7.7 \%$. The blank algae powder was spiked with $\mathrm{C}_{1: 0}$, $\mathrm{C}_{16: 0}, \mathrm{C}_{18: 0}$ and $\mathrm{C}_{22: 6}$ in FAME form at three levels at the following concentrations:

- $\mathrm{C}_{14: 0}$ was spiked to final concentrations of approximately $1.7 \%, 2.0 \%$ and $3.3 \%$ $(\mathrm{w} / \mathrm{v})$,

- $\mathrm{C}_{16}: 0$ was spiked to final concentrations of approximately $18.5 \%, 21.5 \%$ and $33.6 \%(\mathrm{w} / \mathrm{v})$,

- C18:0 was spiked to final concentrations of approximately $0.6 \%, 0.8 \%$ and $1.4 \%(\mathrm{w} / \mathrm{v})$, and

- C22:6 was spiked to final concentrations of approximately $10.1 \%, 12.3 \%$ and 
$21.6 \%(\mathrm{w} / \mathrm{v})$.

The blank algae powder and defatted algae powder were extracted and analyzed in six replicates on Day 1 (first analyst only), and in three replicates on Day 2 by both the primary and secondary analysts. The average of the endogenous levels found in the blank was added to the amount spiked prior to the spike recoveries being calculated.

\section{Precision}

The spike data described from the accuracy experiments were analyzed for precision in terms of intra-day and inter-day variability. Intra-day precision was calculated for each analyte at each concentration. Inter-day precision was calculated to include data from all three analysis days, for each analyte.

\section{Limit of Detection (LOD) and Limit of Quantification (LOQ)}

To determine the method LOD and LOQ for $\mathrm{C}_{14: 0}, \mathrm{C}_{16: 0}, \mathrm{C}_{18: 0}$ and $\mathrm{C}_{22: 6}$, ten replicate determinations of algae powder were made and the mean and standard deviations (SD) for each analyte were calculated. The LOD was calculated as three times the SD and the LOQ was calculated as ten times the SD.

\section{Stability}

In order to assess the stability of DHA in Aurantiochytrium limacinum, alternative batches were prepared containing the antioxidants, ethoxyquin and Duralox (Videka, Elven, France). The antioxidants were added post-heterotrophic fermentation under mixing in a chilled holding tank prior to spray drying. Ethoxyquin was added to three independent batches of Aurantiochytrium limacinum at a concentration of $200 \mathrm{mg} / \mathrm{kg} \mathrm{DM}$ and the stability was determined over 24 months. Duralox was added to four batches of Aurantiochytrium limacinum at a concentration of $1000 \mathrm{mg} / \mathrm{kg} \mathrm{DM}$ and the stability was assessed over six months.

\section{Results}

\section{Specificity}

The analysis of the algae powder confirmed the presence of endogenous levels of each investigated analyte and the results are included in Table 1. A chromatogram of the low concentration spike sample was compared to a chromatogram of the blank algae. The specificity of the method was demonstrated by the ability to distinguish between each FAME analyte from other compounds present in the matrix.

\section{Linearity}

The method was linear over the calibration ranges for all FAME analytes $\mathrm{C}_{14: 0}$, $\mathrm{C}_{16: 0}$ and $\mathrm{C}_{18: 0}$ and $\mathrm{C}_{22: 6}$. The coefficients of determination, $\mathrm{R}^{2}$, were consistently at 1.000 for each analyte's respective calibration curves. They were within the acceptable criteria of $R^{2} \geq 0.990$ ( $\left.R \geq 0.995\right)$ (Table 2).

\section{Accuracy}

To assess the accuracy, the mean of nine percent recovery determinations by the primary analyst and three by the secondary analyte were obtained. The spike recoveries for the four monitored analytes in the algae powder were calculated 
Table 1. Fatty acid \% content in an unextracted Aurantiochytrium limacinum algae dried biomass.

\begin{tabular}{ccccc}
\hline Replicate No. & $\mathrm{C}_{14: 0}$ & $\mathrm{C}_{16: 0}$ & $\mathrm{C}_{18: 0}$ & $\mathrm{C}_{22: 6}$ \\
\hline 1 & 2.59 & 34.7 & 1.06 & 19.1 \\
2 & 2.62 & 35.1 & 1.06 & 19.3 \\
3 & 2.63 & 35.1 & 1.06 & 19.2 \\
4 & 2.62 & 35.1 & 1.06 & 19.3 \\
5 & 2.68 & 35.9 & 1.08 & 19.8 \\
6 & 2.64 & 35.5 & 1.07 & 19.6 \\
7 & 2.54 & 34.4 & 1.07 & 18.9 \\
8 & 2.61 & 35.3 & 1.07 & 19.3 \\
9 & 2.60 & 35.0 & 1.07 & 19.3 \\
Mean & 2.61 & 35.1 & 1.07 & 19.3 \\
SD & 0.038 & 0.438 & 0.010 & 0.270 \\
RSD (\%) & 1.47 & 1.25 & 0.900 & 1.40 \\
\hline
\end{tabular}

Weight of FA in FAME form (g) $=\left[\right.$ (Response FAME$^{*}$ Weight of IS $^{\star}$ Response Factor IS) $] /$ Response IS ${ }^{*}$ Response Factor FAME; Weight of FA in Fatty Acid Form $(\mathrm{g})=$ Weight of FA in FAME form $(\mathrm{g})^{*}$ Conversion factor for FAME form to FA form; \%FA = Weight of FA in Fatty Acid Form (g)/weight of sample $(\mathrm{g}) * 100$ [27]; RSD $(\%)=(\mathrm{SD} / \text { Mean })^{\star} 100$.

Table 2. Correlation coefficients and linearity equations for fatty acid analysis of unextracted biomass of Aurantiochytrium limacinum powder.

\begin{tabular}{cccccc}
\hline ID & Parameter & $\mathrm{C}_{14: 0}$ & $\mathrm{C}_{16: 0}$ & $\mathrm{C}_{18: 0}$ & $\mathrm{C}_{22: 6}$ \\
\hline Analysis \#1 & $\mathrm{R}^{2}$ & 1.000 & 1.000 & 1.000 & 1.000 \\
& linear equation & $\mathrm{y}=1.103 \mathrm{x}$ & $\mathrm{y}=1.150 \mathrm{x}$ & $\mathrm{y}=1.161 \mathrm{x}$ & $\mathrm{y}=1.102 \mathrm{x}$ \\
Analysis \#2 & $\mathrm{R}^{2}$ & 1.000 & 1.000 & 1.000 & 1.000 \\
& linear equation & $\mathrm{y}=1.211 \mathrm{x}$ & $\mathrm{y}=1.193 \mathrm{x}$ & $\mathrm{y}=1.122 \mathrm{x}$ & $\mathrm{y}=1.307 \mathrm{x}$ \\
\hline
\end{tabular}

and ranged from $91.6 \%$ to $107.3 \%$, which was within the acceptable criteria of $90 \%-110 \%$. The SD of the recoveries was further calculated to determine the $\%$ relative standard deviation (\%RSD). See Table 3 for the complete summary of results.

The spike recoveries for the four monitored analytes in the defatted algae were also calculated and ranged from $80 \%$ to $119 \%$. This was outside the desired criteria of $90 \%-110 \%$. See Table 4 for the summary of the results. We have to note that the de-fatted algae powder was prepared only as a complementary evaluation to support the accuracy and precision of the method on the main matrix i.e. Aurantiochytrium limacinum algae powder. The impact of the defatting process is likely to have altered the overall stability of the matrix, with a consequent increase in the variability of the result compared to those obtained in the primary matrix. 
Table 3. Accuracy of fatty acids recoveries (\%) from the unextracted biomass of Aurantiochytrium limacinum algae powder spiked to three concentration levels.

\begin{tabular}{|c|c|c|c|c|c|c|c|c|c|c|c|c|}
\hline Primary Analyst & $\underline{\mathrm{C}}_{14: 0}$ & $\underline{\mathrm{C}}_{16: 0}$ & $\underline{C}_{18: 0}$ & $\underline{\mathrm{C}}_{22: 6}$ & $\underline{\mathrm{C}}_{14: 0}$ & $\underline{\mathrm{C}}_{16: 0}$ & $\underline{\mathrm{C}}_{18: 0}$ & $\underline{\mathrm{C}}_{22: 6}$ & $\underline{\mathrm{C}}_{14: 0}$ & $\underline{C}_{16: 0}$ & $\underline{\mathrm{C}}_{18: 0}$ & $\underline{\mathrm{C}}_{22: 6}$ \\
\hline Spiked Conc (\%) & 3.2 & 41.3 & 1.7 & 25.7 & 3.9 & 48.0 & 2.4 & 32.4 & 4.6 & 54.6 & 3.0 & 39.1 \\
\hline Replicate-1 & 100.8 & 99.9 & 97.5 & 100.9 & 103.7 & 102.8 & 100.1 & 106.0 & 103.6 & 101.9 & 100.1 & 107.2 \\
\hline Replicate-2 & 101.9 & 101.4 & 98.7 & 102.6 & 104.4 & 103.7 & 100.8 & 107.3 & 100.8 & 99.3 & 97.4 & 104.1 \\
\hline Replicate-3 & 102.0 & 101.3 & 99.1 & 102.7 & 100.7 & 99.9 & 97.7 & 103.6 & 101.9 & 100.4 & 98.2 & 104.7 \\
\hline Replicate-4 & 105.0 & 104.5 & 101.7 & 97.7 & 102.1 & 101.2 & 98.8 & 103.7 & 100.6 & 99.1 & 96.8 & 103.9 \\
\hline Replicate-5 & 102.2 & 101.8 & 99.4 & 103.2 & 101.2 & 100.4 & 98.9 & 103.8 & 101.6 & 100.2 & 97.8 & 103.9 \\
\hline Replicate- 6 & 103.6 & 103.0 & 100.6 & 104.1 & 104.0 & 103.1 & 100.5 & 106.2 & 100.5 & 99.1 & 96.8 & 103.1 \\
\hline Replicate-7 & 101.1 & 101.4 & 99.2 & 103.3 & 102.5 & 102.0 & 99.8 & 103.8 & 101.3 & 101.3 & 99.0 & 104.3 \\
\hline Replicate- 8 & 99.5 & 100.0 & 98.7 & 101.1 & 96.2 & 97.2 & 91.6 & 96.8 & 101.0 & 100.3 & 97.5 & 102.4 \\
\hline Replicate-9 & 100.4 & 100.7 & 98.5 & 101.7 & 101.1 & 100.4 & 99.9 & 104.9 & 103.1 & 103.5 & 101.4 & 106.8 \\
\hline $\begin{array}{l}\text { Mean, primary } \\
\text { analyst }\end{array}$ & 101.8 & 101.6 & 99.3 & 101.9 & 101.8 & 101.2 & 98.7 & 104.0 & 101.6 & 100.6 & 98.3 & 104.5 \\
\hline Std Deviation & 1.7 & 1.4 & 1.2 & 1.9 & 2.5 & 2.0 & 2.8 & 3.0 & 1.1 & 1.5 & 1.6 & 1.6 \\
\hline RSD (\%) & 1.6 & 1.4 & 1.2 & 1.9 & 2.4 & 2.0 & 2.9 & 2.9 & 1.1 & 1.4 & 1.6 & 1.5 \\
\hline Secondary Analyst & $\mathrm{C}_{14: 0}$ & $\mathrm{C}_{16: 0}$ & $\mathrm{C}_{18: 0}$ & $\mathrm{C}_{22: 6}$ & $\mathrm{C}_{14: 0}$ & $\mathrm{C}_{16: 0}$ & $\mathrm{C}_{18: 0}$ & $\mathrm{C}_{22: 6}$ & $\mathrm{C}_{14: 0}$ & $\mathrm{C}_{16: 0}$ & $\mathrm{C}_{18: 0}$ & $\mathrm{C}_{22: 6}$ \\
\hline Replicate-1 & 99.3 & 97.7 & 95.4 & 97.4 & 101.4 & 99.7 & 98.3 & 101.7 & 101.7 & 99.8 & 97.9 & 101.6 \\
\hline Replicate-2 & 100.5 & 99.3 & 97.3 & 99.2 & 101.5 & 100.1 & 98.1 & 101.5 & 101.6 & 100.0 & 97.6 & 102.2 \\
\hline Replicate-3 & 98.0 & 96.7 & 96.0 & 97.4 & 100.2 & 98.9 & 96.7 & 100.1 & 100.7 & 99.1 & 97.2 & 101.1 \\
\hline $\begin{array}{l}\text { Mean, secondary } \\
\text { analyst }\end{array}$ & 99.2 & 97.9 & 96.2 & 98.0 & 101.0 & 99.6 & 97.7 & 101.1 & 101.3 & 99.6 & 97.6 & 101.6 \\
\hline $\begin{array}{c}\text { RE (\%) to Primary } \\
\text { Analyst }\end{array}$ & -2.5 & -3.6 & -3.0 & -3.9 & -0.7 & -1.6 & -1.0 & -2.8 & -0.3 & -1.0 & -0.8 & -2.7 \\
\hline
\end{tabular}

$\operatorname{RSD}\left(\%=(\mathrm{SD} /\right.$ Mean $) * 100 ; \mathrm{RE}($ Relative error $(\%))=\left((\text { mean, } 2 \text { nd analyst }- \text { mean, } 1 \text { st analyst })^{\star}(\right.$ mean, 1 st analyst $){ }^{*} 100$.

\section{Precision}

The precision of the method was established by calculating the coefficient of variation $(\mathrm{CV}, \%)$ from the replicate determinations of the primary and secondary analysts. The precision ranged from $1.9 \%$ to $2.7 \%$ for the spiked algae powder and $9.8 \%$ to $11.5 \%$ for the defatted algae powder. See Table 5 and Table 6 for the complete summaries.

\section{Limit of Detection (LOD) and Limit of Quantification (LOQ)}

The results of LOD and LOQ determinations are included in Table 7. The LOD of the respective fatty acids were determined as $0.12 \%\left(\mathrm{C}_{14: 0}\right), 1.8 \%\left(\mathrm{C}_{16: 0}\right)$, $0.06 \%\left(\mathrm{C}_{18: 0}\right)$ and $1.2 \%\left(\mathrm{C}_{22: 6}\right)$ and the LOQs were as $0.4 \%\left(\mathrm{C}_{14: 0}\right), 6 \%\left(\mathrm{C}_{16: 0}\right), 0.2 \%$ $\left(\mathrm{C}_{18: 0}\right)$ and $4 \%\left(\mathrm{C}_{22: 6}\right)$.

\section{Stability of DHA in Aurantiochytrium limacinum Biomass with a Natural or Synthetic Antioxidant}

The stability data over 24 months for Aurantiochytrium limacinum containing the synthetic antioxidant, ethoxyquin, demonstrates that ethoxyquin was very 
Table 4. Accuracy of fatty acid recoveries (\%) in de-fatted unextracted biomass of Aurantiochytrium limacinum algae powder spiked to three concentration levels.

\begin{tabular}{|c|c|c|c|c|c|c|c|c|c|c|c|c|}
\hline Primary Analyst & $\mathrm{C}_{14: 0}$ & $\mathrm{C}_{16: 0}$ & $\mathrm{C}_{18: 0}$ & $\mathrm{C}_{22: 6}$ & $\mathrm{C}_{14: 0}$ & $C_{16: 0}$ & $\mathrm{C}_{18: 0}$ & $\mathrm{C}_{22: 6}$ & $\mathrm{C}_{14: 0}$ & $\mathrm{C}_{16: 0}$ & $\mathrm{C}_{18: 0}$ & $\mathrm{C}_{22: 6}$ \\
\hline Approx. Spiked Conc (\%) & 1.7 & 18 & 0.6 & 10 & 2.0 & 22.0 & 0.8 & 12 & 3.3 & 34 & 1.4 & 22 \\
\hline Replicate-1 & 96.0 & 96.0 & 86.6 & 117.1 & 95.4 & 90.6 & 96.6 & 106.6 & 92.8 & 86.0 & 88.7 & 106.2 \\
\hline Replicate-2 & 87.2 & 88.2 & 88.5 & 113.1 & 89.7 & 82.6 & 86.9 & 102.8 & 96.8 & 91.3 & 91.9 & 112.8 \\
\hline Replicate-3 & 92.7 & 100.3 & 95.1 & 113.0 & 100.8 & 96.7 & 99.7 & 117.4 & 100.5 & 94.3 & 93.2 & 113.6 \\
\hline Replicate-4 & 97.5 & 95.6 & 97.8 & 119.2 & 99.1 & 93.9 & 88.9 & 108.1 & 100.1 & 95.0 & 94.5 & 114.4 \\
\hline Replicate-5 & 89.1 & 82.3 & 80.7 & 111.8 & 93.9 & 89.9 & 91.0 & 115.5 & 96.8 & 91.5 & 91.8 & 111.3 \\
\hline Replicate-6 & 99.1 & 94.7 & 91.9 & 112.8 & 99.6 & 96.0 & 91.5 & 114.5 & 92.7 & 86.1 & 89.1 & 106.6 \\
\hline Replicate-7 & 94.2 & 93.3 & 100.3 & 117.1 & 87.3 & 83.2 & 94.1 & 108.1 & 91.8 & 86.6 & 83.1 & 103.9 \\
\hline Replicate-8 & 82.9 & 82.9 & 97.0 & 100.7 & 85.6 & 81.0 & 86.5 & 104.9 & 92.1 & 89.3 & 90.0 & 109.6 \\
\hline Replicate-9 & 93.5 & 90.0 & 96.5 & 113.8 & 82.0 & 80.9 & 87.6 & 104.2 & 90.8 & 87.1 & 88.0 & 105.1 \\
\hline Mean, primary analyst & 92.5 & 91.5 & 92.7 & 113.2 & 92.6 & 88.3 & 91.4 & 109.1 & 94.9 & 89.7 & 90.0 & 109.3 \\
\hline Std Deviation & 5.2 & 6.1 & 6.3 & 5.3 & 6.8 & 6.5 & 4.6 & 5.3 & 3.7 & 3.5 & 3.4 & 3.9 \\
\hline RSD (\%) & 5.6 & 6.7 & 6.8 & 4.7 & 7.3 & 7.3 & 5.0 & 4.9 & 3.9 & 3.9 & 3.8 & 3.6 \\
\hline Secondary Analyst & $\mathrm{C}_{14: 0}$ & $\mathrm{C}_{16: 0}$ & $\mathrm{C}_{18: 0}$ & $\mathrm{C}_{22: 6}$ & $\mathrm{C}_{14: 0}$ & $C_{16: 0}$ & $\mathrm{C}_{18: 0}$ & $\mathrm{C}_{22: 6}$ & $\mathrm{C}_{14: 0}$ & $\mathrm{C}_{16: 0}$ & $\mathrm{C}_{18: 0}$ & $\mathrm{C}_{22: 6}$ \\
\hline Spike-1 & 87.3 & 88.6 & 83.5 & 115.6 & 86.9 & 83.8 & 80.3 & 98.8 & 97.5 & 94.8 & 93.5 & 114.8 \\
\hline Spike-2 & 86.3 & 80.9 & 81.3 & 112.3 & 87.8 & 81.4 & 81.0 & 101.1 & 92.7 & 88.4 & 86.4 & 106.3 \\
\hline Spike-3 & 89.4 & 88.4 & 94.9 & 111.9 & 88.9 & 85.6 & 80.3 & 106.2 & 97.2 & 93.0 & 94.7 & 113.4 \\
\hline Mean, secondary analyst & 87.7 & 86.0 & 86.6 & 113.3 & 87.9 & 83.6 & 80.5 & 102.0 & 95.8 & 92.1 & 91.5 & 111.5 \\
\hline $\mathrm{RE}(\%)$ to Primary Analyst & -5.2 & -6.0 & -6.6 & 0.1 & -5.1 & -5.3 & -11.9 & -6.5 & 0.9 & 2.7 & 1.7 & 2.0 \\
\hline
\end{tabular}

$\operatorname{RSD}\left(\%=(\mathrm{SD} /\right.$ Mean $) * 100 ; \mathrm{RE}($ Relative error $(\%))=\left((\right.$ mean, 2 nd analyst - mean, 1 st analyst $) *($ mean, 1 st analyst $){ }^{*} 100$.

Table 5. Precision of fatty acid recoveries (\%) from the unextracted biomass of Aurantiochytrium limacinum algae powder spiked to three concentration levels.

\begin{tabular}{|c|c|c|c|c|c|c|c|c|c|c|c|c|}
\hline Intra-day Precision: & $\mathrm{C}_{14: 0}$ & $\mathrm{C}_{16: 0}$ & $\mathrm{C}_{18: 0}$ & $\mathrm{C}_{22: 6}$ & $\mathrm{C}_{14: 0}$ & $\mathrm{C}_{16: 0}$ & $\mathrm{C}_{18: 0}$ & $\mathrm{C}_{22: 6}$ & $\mathrm{C}_{14: 0}$ & $\mathrm{C}_{16: 0}$ & $\mathrm{C}_{18: 0}$ & $\mathrm{C}_{22: 6}$ \\
\hline Approx. Spiked Conc (\%) & 3.2 & 41.3 & 1.7 & 25.7 & 3.9 & 48.0 & 2.4 & 32.4 & 4.6 & 54.6 & 3.0 & 39.1 \\
\hline Day $1 \bar{x} \quad(n=6)$ & 102.6 & 102.0 & 99.5 & 101.9 & 102.7 & 101.9 & 99.5 & 105.1 & 101.5 & 100.0 & 97.9 & 104.5 \\
\hline $\mathrm{SD}$ & 1.5 & 1.6 & 1.5 & 2.3 & 1.5 & 1.6 & 1.2 & 1.6 & 1.2 & 1.1 & 1.2 & 1.4 \\
\hline$\% \mathrm{CV}$ & 1.5 & 1.6 & 1.5 & 2.3 & 1.5 & 1.5 & 1.2 & 1.5 & 1.2 & 1.1 & 1.2 & 1.4 \\
\hline Day $2 \bar{x} \quad(n=3)$ & 100.3 & 100.7 & 98.8 & 102.1 & 99.9 & 99.9 & 97.1 & 101.8 & 101.8 & 101.7 & 99.3 & 104.5 \\
\hline SD & 0.8 & 0.7 & 0.4 & 1.1 & 3.3 & 2.5 & 4.8 & 4.4 & 1.1 & 1.6 & 2.0 & 2.2 \\
\hline$\% \mathrm{CV}$ & 0.8 & 0.7 & 0.4 & 1.1 & 3.3 & 2.5 & 4.9 & 4.3 & 1.1 & 1.6 & 2.0 & 2.1 \\
\hline Day $3 \bar{x} \quad(n=3)$ & 99.2 & 97.9 & 96.2 & 98.0 & 101.0 & 99.6 & 97.7 & 101.1 & 101.3 & 99.6 & 97.6 & 101.6 \\
\hline $\mathrm{SD}$ & 1.3 & 1.3 & 0.9 & 1.0 & 0.8 & 0.6 & 0.9 & 0.9 & 0.5 & 0.5 & 0.3 & 0.5 \\
\hline$\% \mathrm{CV}$ & 1.3 & 1.3 & 1.0 & 1.0 & 0.8 & 0.6 & 0.9 & 0.8 & 0.5 & 0.5 & 0.3 & 0.5 \\
\hline Inter-day Precision: & $\mathrm{C}_{14: 0}$ & $\mathrm{C}_{16: 0}$ & $\mathrm{C}_{18: 0}$ & $\mathrm{C}_{22: 6}$ & $\mathrm{C}_{14: 0}$ & $\mathrm{C}_{16: 0}$ & $\mathrm{C}_{18: 0}$ & $\mathrm{C}_{22: 6}$ & $\mathrm{C}_{14: 0}$ & $\mathrm{C}_{16: 0}$ & $\mathrm{C}_{18: 0}$ & $\mathrm{C}_{22: 6}$ \\
\hline $\bar{x} \quad(n=3)$ & 101.2 & 100.6 & 98.5 & 100.9 & 101.6 & 100.8 & 98.4 & 103.3 & 101.5 & 100.3 & 98.2 & 103.8 \\
\hline $\mathrm{SD}$ & 1.9 & 2.1 & 1.8 & 2.4 & 2.2 & 1.9 & 2.5 & 2.9 & 1.0 & 1.3 & 1.4 & 1.9 \\
\hline$\% \mathrm{CV}$ & 1.9 & 2.1 & 1.8 & 2.4 & 2.1 & 1.9 & 2.5 & 2.8 & 1.0 & 1.3 & 1.4 & 1.8 \\
\hline
\end{tabular}


Table 6. Precision of fatty acid recoveries (\%) from de-fatted unextracted biomass of Aurantiochytrium limacinum algae powder spiked to three concentration levels.

\begin{tabular}{|c|c|c|c|c|c|c|c|c|c|c|c|c|}
\hline Intra-day Precision: & $\mathrm{C}_{14: 0}$ & $\mathrm{C}_{16: 0}$ & $\mathrm{C}_{18: 0}$ & $\mathrm{C}_{22: 6}$ & $\mathrm{C}_{14: 0}$ & $\mathrm{C}_{16: 0}$ & $\mathrm{C}_{18: 0}$ & $\mathrm{C}_{22: 6}$ & $\mathrm{C}_{14: 0}$ & $\mathrm{C}_{16: 0}$ & $\mathrm{C}_{18: 0}$ & $\mathrm{C}_{22: 6}$ \\
\hline Approx. Spiked Conc (\%) & 1.7 & 18 & 0.6 & 10 & 2.0 & 22.0 & 0.8 & 12 & 3.3 & 34 & 1.4 & 22 \\
\hline Day $1 \quad \bar{x} \quad(n=6)$ & 93.6 & 92.9 & 90.1 & 114.5 & 96.4 & 91.6 & 92.4 & 110.8 & 96.6 & 90.7 & 91.5 & 110.8 \\
\hline $\mathrm{SD}$ & 4.8 & 6.5 & 6.2 & 2.9 & 4.2 & 5.2 & 4.8 & 5.8 & 3.4 & 3.9 & 2.3 & 3.6 \\
\hline$\% \mathrm{CV}$ & 5.1 & 7.0 & 6.9 & 2.6 & 4.4 & 5.7 & 5.2 & 5.2 & 3.5 & 4.3 & 2.5 & 3.2 \\
\hline Day $2 \bar{x} \quad(n=3)$ & 90.2 & 88.7 & 97.9 & 110.5 & 85.0 & 81.7 & 89.4 & 105.7 & 91.6 & 87.7 & 87.0 & 106.2 \\
\hline $\mathrm{SD}$ & 6.3 & 5.3 & 2.1 & 8.7 & 2.7 & 1.3 & 4.1 & 2.1 & 0.7 & 1.4 & 3.6 & 3.0 \\
\hline$\% \mathrm{CV}$ & 7.0 & 6.0 & 2.1 & 7.8 & 3.2 & 1.6 & 4.6 & 2.0 & 0.7 & 1.6 & 4.1 & 2.8 \\
\hline Day $3 \bar{x} \quad(n=3)$ & 87.7 & 86.0 & 86.6 & 113.3 & 87.9 & 83.6 & 80.5 & 102.0 & 95.8 & 92.1 & 91.5 & 111.5 \\
\hline SD & 1.6 & 4.4 & 7.3 & 2.0 & 1.0 & 2.1 & 0.4 & 3.8 & 2.7 & 3.3 & 4.5 & 4.6 \\
\hline$\% \mathrm{CV}$ & 1.8 & 5.1 & 8.4 & 1.8 & 1.1 & 2.5 & 0.5 & 3.7 & 2.8 & 3.6 & 4.9 & 4.1 \\
\hline Inter-day Precision: & $\mathrm{C}_{14: 0}$ & $C_{16: 0}$ & $\mathrm{C}_{18: 0}$ & $\mathrm{C}_{22: 6}$ & $\mathrm{C}_{14: 0}$ & $\mathrm{C}_{16: 0}$ & $\mathrm{C}_{18: 0}$ & $\mathrm{C}_{22: 6}$ & $\mathrm{C}_{14: 0}$ & $C_{16: 0}$ & $\mathrm{C}_{18: 0}$ & $\mathrm{C}_{22: 6}$ \\
\hline Average & 91.3 & 90.1 & 91.2 & 113.2 & 91.4 & 87.1 & 88.7 & 107.4 & 95.2 & 90.3 & 90.4 & 109.8 \\
\hline $\mathrm{SD}$ & 5.0 & 6.1 & 6.8 & 4.6 & 6.2 & 6.0 & 6.3 & 5.8 & 3.4 & 3.5 & 3.5 & 4.0 \\
\hline$\% \mathrm{CV}$ & 5.5 & 6.7 & 7.5 & 4.1 & 6.7 & 6.9 & 7.1 & 5.4 & 3.5 & 3.8 & 3.9 & 3.7 \\
\hline
\end{tabular}

Table 7. Limit of Detection (LOD) and Limit of Quantitation (LOQ) in unextracted biomass of Aurantiochytrium limacinum algae powder spiked to three concentration levels.

\begin{tabular}{|c|c|c|c|c|}
\hline Replicate No. & $\% \mathrm{C}_{14: 0}$ & $\% \mathrm{C}_{16: 0}$ & $\% \mathrm{C}_{18: 0}$ & $\% \mathrm{C}_{22: 6}$ \\
\hline Replicate-1 & 2.56 & 34.59 & 1.07 & 18.86 \\
\hline Replicate-2 & 2.65 & 35.96 & 1.10 & 19.78 \\
\hline Replicate-3 & 2.60 & 35.08 & 1.06 & 19.27 \\
\hline Replicate-4 & 2.60 & 35.15 & 1.06 & 19.34 \\
\hline Replicate-5 & 2.66 & 36.01 & 1.09 & 19.80 \\
\hline Replicate- 6 & 2.60 & 35.01 & 1.06 & 19.06 \\
\hline Replicate-7 & 2.61 & 35.21 & 1.07 & 19.32 \\
\hline Replicate-8 & 2.60 & 35.11 & 1.07 & 19.28 \\
\hline Replicate-9 & 2.53 & 34.27 & 1.05 & 18.73 \\
\hline Replicate-10 & 2.53 & 34.28 & 1.05 & 18.67 \\
\hline Average & 2.59 & 35.07 & 1.07 & 19.21 \\
\hline $\mathrm{SD}$ & 0.04 & 0.60 & 0.02 & 0.4 \\
\hline $\operatorname{LOD}(3 \times \mathrm{SD})$ & 0.12 & 2 & 0.06 & 1.2 \\
\hline LOQ $(10 \times \mathrm{SD})$ & 0.4 & 6 & 0.2 & 4 \\
\hline
\end{tabular}

effective protecting the LC-PUFA, including DHA, from oxidation (Table 8). Results for all data points over the study were within $+/-3.5 \%$ of the initial determination. As ethoxyquin is understood to have high antioxidant efficiency and stability and protects lipids against peroxidation, the consistency of DHA over 24 months was not unexpected [32].

Table 9 shows the results for the stability assessment of DHA in Aurantiochytrium limacinum containing Duralox and shows that DHA can be effectively 
Table 8. The stability of DHA (\%) in in unextracted biomass of Aurantiochytrium limacinum powder over 24 months using the antioxidant, ethoxyquin.

\begin{tabular}{cccccc}
\hline Time & Mean $\%$ & SD & Minimum & Maximum & Range \\
\hline (Month) & $(\mathrm{n}=3)$ & & & & \\
\hline 0 & 16.56 & 0.51 & 16.08 & 17.1 & 1.02 \\
1 & 17.56 & 0.70 & 17.14 & 18.36 & 1.22 \\
2 & 17.36 & 0.51 & 16.89 & 17.91 & 1.02 \\
3 & 17.16 & 0.59 & 16.81 & 17.84 & 1.03 \\
6 & 17.30 & 0.42 & 17.05 & 17.79 & 0.74 \\
9 & 17.16 & 1.06 & 16.36 & 18.36 & 2.00 \\
12 & 16.93 & 0.43 & 16.57 & 17.4 & 0.83 \\
15 & 17.06 & 0.55 & 16.64 & 17.68 & 1.04 \\
18 & 16.16 & 0.44 & 15.75 & 16.62 & 0.87 \\
21 & 16.01 & 0.40 & 15.7 & 16.46 & 0.76 \\
24 & 17.16 & 0.69 & 16.73 & 17.96 & 1.23 \\
\hline
\end{tabular}

Table 9. The stability of DHA in in unextracted biomass of Aurantiochytrium limacinum powder over six months using the antioxidant, Duralox ${ }^{\oplus}$.

\begin{tabular}{cccccc}
\hline Time & Mean \% & SD & Minimum & Maximum & Range \\
\hline (Month) & $(\mathrm{n}=4)$ & & & & \\
\hline 0 & 17.86 & 0.19 & 17.71 & 18.11 & 0.40 \\
1 & 17.94 & 0.23 & 17.66 & 18.23 & 0.57 \\
2 & 18.04 & 0.14 & 17.88 & 18.23 & 0.35 \\
3 & 17.81 & 0.30 & 17.52 & 18.22 & 0.70 \\
6 & 18.20 & 0.37 & 17.71 & 18.56 & 0.85 \\
\hline
\end{tabular}

stabilized over six months with the inclusion of this antioxidant. Results for all data points over the study were within $+/-2 \%$ of the initial determination.

\section{Conclusion}

The suitability of the AOAC method 996.06 for the determination of DHA (C22:6) and three additional fatty acids $\left(\mathrm{C}_{14: 0}, \mathrm{C}_{16: 0}\right.$ and $\left.\mathrm{C}_{18: 0}\right)$ in a dried microalgae biomass was investigated. The method was found to be linear over the following ranges for each FAME analyte; 50 to $15,000 \mu \mathrm{g} / \mathrm{ml}\left(\mathrm{C}_{14: 0}\right), 300$ to 95,000 $\left(\mathrm{C}_{16: 0}\right), 25$ to $15,000\left(\mathrm{C}_{18: 0}\right)$ and 300 to 59,375 $\left(\mathrm{C}_{22: 6}\right)$. The method was verified for use by examining the method parameters, accuracy and precision, specificity and by determining the LOD and LOQ for each analyte. The results of the accuracy and precision experiments were within acceptable limits for the primary matrix, Aurantiochytrium limacinum biomass. The robustness of the method was confirmed through limited variability of the analysis precision and accuracy when 
investigated by a second analyst. Therefore, the method is deemed fit for purpose for the analysis of the microalgae, Aurantiochytrium limacinum. The method could be further used by other researchers who are investigating Aurantiochytrium limacinum and who need to elucidate the fatty acid composition in various applications. The method could also be employed in examining other similar algal species. The present authors intend to use the method for routine analysis, quality control \& product release. The results of the stability assessments show that Duralox ${ }^{\circledast}$ can be used as an alternative to ethoxyquin for stabilizing DHA over six months. Further analysis will be required to show the efficiency over a long time period.

\section{Acknowledgements}

Experimental analyses were performed by Huey Kuan, Gloria Wang, Yuki Nakagawa of Merieux NutriSciences (Burnaby). The authors would like to express their gratitude to Ms. Rebecca Timmons (Alltech USA) for her technical input on handling Aurantiochytrium sp. biomass and analysis.

\section{Declaration of Conflicting Interests}

The funders had no role in the design of the study; in the collection, analyses, or the interpretation of data. GD, AY and CM work for Alltech, who sponsored the research, contributed to the writing of the manuscript and in the decision to publish the results.

\section{Conflicts of Interest}

The authors declare that there is no conflict of interest regarding the publication of this paper.

\section{References}

[1] Ruxton, C.H.S., Reed, S.C., Simpson, M.J.A. and Millington, K.J. (2004) The Health Benefits of Omega-3 Polyunsaturated Fatty Acids: A Review of the Evidence. Journal of Human Nutrition and Dietetics, 17, 449-459. https://doi.org/10.1111/j.1365-277X.2004.00552.x

[2] Grosso, G., Pajak, A., Marventano, S., Castellano, S., Galvano, F., Bucolo, C., Drago, F. and Caraci, F. (2014) Role of Omega-3 Fatty Acids in the Treatment of Depressive Disorders: A Comprehensive Meta-Analysis of Randomized Clinical Trials. PLoS ONE, 9, e96905. https://doi.org/10.1371/journal.pone.0096905

[3] Calder, P.C. (2015) Marine Omega-3 Fatty Acids and Inflammatory Processes: Effects, Mechanisms and Clinical Relevance. Biochimica et Biophysica Acta-Molecular and Cell Biology of Lipids, 1851, 469-484. https://doi.org/10.1016/j.bbalip.2014.08.010

[4] Swanson, D., Block, R. and Mousa, S.A. (2012) Omega-3 Fatty Acids EPA and DHA: Health Benefits throughout Life. Advances in Nutrition, 3, 1-7. https://doi.org/10.3945/an.111.000893

[5] Sheppard, K.W. and Cheatham, C.L. (2018) Omega-6/Omega-3 Fatty Acid Intake of Children and Older Adults in the U.S.: Dietary Intake in Comparison to Current Dietary Recommendations and the Healthy Eating Index. Lipids in Health and Dis- 
ease, 17, 1-12. https://doi.org/10.1186/s12944-018-0693-9

[6] Meyer, B.J., Mann, N.J., Lewis, J.L., Milligan, G.C., Sinclair, A.J. and Howe, P.R.C. (2003) Dietary Intakes and Food Sources of Omega-6 and Omega-3 Polyunsaturated Fatty Acids. Lipids, 38, 391-398. https://doi.org/10.1007/s11745-003-1074-0

[7] Masood, A., Stark, K.D. and Salem, N. (2005) A Simplified and Efficient Method for the Analysis of Fatty Acid Methyl Esters Suitable for Large Clinical Studies. The Journal of Lipid Research, 46, 2299-2305. https://doi.org/10.1194/jlr.D500022-JLR200

[8] Micha, R., et al. (2014) Global, Regional, and National Consumption Levels of Dietary Fats and Oils in 1990 and 2010: A Systematic Analysis Including 266 Country-Specific Nutrition Surveys. BMJ, 348, 1-20. https://doi.org/10.1136/bmj.g2272

[9] Rymer, C. and Givens, D.I. (2005) n-3 Fatty Acid Enrichment of Edible Tissue of Poultry: A Review. Lipids, 40, 121-130. https://doi.org/10.1007/s11745-005-1366-4

[10] Konieczka, P., Barszcz, M., Choct, M. and Smulikowska, S. (2018) The Interactive Effect of Dietary n-6: n-3 Fatty Acid Ratio and Vitamin E Level on Tissue Lipid Peroxidation, DNA Damage in Intestinal Epithelial Cells, and Gut Morphology in Chickens of Different Ages. Poultry Science, 96, 149-158.

https://doi.org/10.3382/ps/pex274

[11] Kitessa, S.M., Gulati, S.K., Ashes, J.R., Fleck, E., Scott, T.W. and Nichols, P.D. (2001) Utilisation of Fish Oil in Ruminants. Animal Feed Science and Technology, 89, 201-208. https://doi.org/10.1016/S0377-8401(00)00232-7

[12] Cieślak, A., et al. (2015) Rapeseed and Fish Oil Mixtures Supplied at Low Dose Can Modulate Milk Fatty Acid Composition without Affecting Rumen Fermentation and Productive Parameters in Dairy Cows. Animal Science Papers and Reports, 33, 357-372.

[13] Salem, N. and Eggersdorfer, M. (2015) Is the World Supply of Omega-3 Fatty Acids Adequate for Optimal Human Nutrition? Current Opinion in Clinical Nutrition \& Metabolic Care, 18, 147-154. https://doi.org/10.1097/MCO.0000000000000145

[14] AbuGhazaleh, A.A., Potu, R.B. and Ibrahim, S. (2009) Short Communication: The Effect of Substituting Fish Oil in Dairy Cow Diets with Docosahexaenoic Acid-Micro Algae on Milk Composition and Fatty Acids Profile. Journal of Dairy Science, 92, 6156-6159. https://doi.org/10.3168/jds.2009-2400

[15] Moran, C.A., Morlacchini, M. and Fusconi, G. (2017) Enhancing the DHA Content in Milk from Dairy Cows by Feeding ALL-G-RICH ${ }^{\mathrm{TM}}$. Journal of Applied Animal Nutrition, 5, 1-9. https://doi.org/10.1017/jan.2017.9

[16] Moran, C.A., Morlacchini, M., Keegan, J.D. and Fusconi, G. (2018) The Effect of Dietary Supplementation with Aurantiochytrium limacinum on Lactating Dairy Cows in Terms of Animal Health, Productivity and Milk Composition. Journal of Animal Physiology and Animal Nutrition, 102, 576-590. https://doi.org/10.1111/jpn.12827

[17] Moran, C.A., Morlacchini, M., Keegan, J.D., Delles, R. and Fusconi, G. (2018) Effects of a DHA-Rich Unextracted Microalgae as a Dietary Supplement on Performance, Carcass Traits and Meat Fatty Acid Profile in Growing-Finishing Pigs. Journal of Animal Physiology and Animal Nutrition, 102, 1026-1038.

https://doi.org/10.1111/jpn.12911

[18] Moran, C.A., Morlacchini, M., Keegan, J.D. and Fusconi, G. (2018) Dietary Supplementation of Finishing Pigs with the Docosahexaenoic Acid-Rich Microalgae, Aurantiochytrium limacinum: Effects on Performance, Carcass Characteristics and Tissue Fatty Acid Profile. Asian-Australasian Journal of Animal Sciences, 31, 
712-720.

[19] Moran, C.A., Currie, D., Keegan, J.D. and Knox, A. (2018) Tolerance of Broilers to Dietary Supplementation with High Levels of the DHA-Rich Microalga, Aurantiochytrium limacinum: Effects on Health and Productivity. Animals, 8, 180-190. https://doi.org/10.3390/ani8100180

[20] Ao, T., Macalintal, L.M., Paul, M.A., Pescatore, A.J., Cantor, A.H., Ford, M.J., Timmons, B. and Dawson, K.A. (2015) Effects of Supplementing Microalgae in Laying Hen Diets on Productive Performance, Fatty-Acid Profile, and Oxidative Stability of Eggs. The Journal of Applied Poultry Research, 24, 394-400. https://doi.org/10.3382/japr/pfv042

[21] Guihéneuf, F. (2015) Lipids and Fatty Acids in Algae: Extraction, Fractionation into Lipid Classes, and Analysis by Gas Chromatography Coupled with Flame Ionization Detector (GC-FID). Methods in Molecular Biology, 1308, 173-190. https://doi.org/10.1007/978-1-4939-2684-8_11

[22] Yao, L., Gerde, J.A., Lee, S.L., Wang, T. and Harrata, K.A. (2015) Microalgae Lipid Characterization. Journal of Agricultural and Food Chemistry, 63, 1773-1787. https://doi.org/10.1021/jf5050603

[23] Tang, B. and Kh, R. (2013) Development of Gas Chromatography Analysis of Fatty Acids in Marine Organisms. Journal of Chromatographic Science, 51, 599-607. https://doi.org/10.1093/chromsci/bmt005

[24] Folch, J., Lees, M. and Sloane Stanley, G.H. (1957) A Simple Method for the Isolation and Purification of Total Lipids from Animal Tissues. The Journal of Biological Chemistry, 226, 497-509.

[25] O’Fallon, J.V., Busboom, J.R., Nelson, M.L. and Gaskins, C.T. (2007) A Direct Method for Fatty Acid Methyl Ester Synthesis: Application to Wet Meat Tissues, Oils, and Feedstuffs. Journal of Animal Science, 85, 1511-1521. https://doi.org/10.2527/jas.2006-491

[26] Bannon, C.D., Craske, J.D. and Hilliker, A.E. (1985) Analysis of Fatty Acid Methyl Esters with High Accuracy and Reliability. IV. Fats with Fatty Acids Containing Four or More Carbon Atoms. Journal of the American Oil Chemists' Society, 62, 1501-1507. https://doi.org/10.1007/BF02541903

[27] Devries, J.W., et al. (1997) Studies in Improvement of Official Method 996.06. Journal of AOAC International, 82, 1146-1155.

[28] Jones, J., Manning, S., Montoya, M., Keller, K. and Poenie, M. (2012) Extraction of Algal Lipids and Their Analysis by HPLC and Mass Spectrometry. Journal of the American Oil Chemists' Society, 89, 1371-1381. https://doi.org/10.1007/s11746-012-2044-8

[29] Woo, S.G., Yoo, K., Lee, L., Bang, S., Lee, M., et al. (2012) Comparison of Fatty Acid Analysis Methods for Assessing Biorefinery Applicability of Wastewater Cultivated Microalgae. Talanta, 97, 103-110. https://doi.org/10.1016/j.talanta.2012.04.002

[30] Blaszczyk, A., Augustyniak, A. and Skolimowski, J. (2013) Ethoxyquin: An Antioxidant Used in Animal Feed. International Journal of Food Science, 2013, Article ID: 585931.

[31] The European Commission (2017) Suspending the Authorisation of Ethoxyquin as a Feed Additive for All Animal Species and Categories. Official Journal of the European Union, L145, 13-17.

[32] EFSA (2015) Safety and Efficacy of Ethoxyquin (6-ethoxy-1,2-dihydro-2,2,4 trimethylquinoline) for All Animal Species. EFSA Journal, 13, 4272. 